\title{
ARTYKUtY
}

Klio. Czasopismo poświęcone dziejom Polski i powszechnym

PL ISSN 1643-8191, t. 41 (2)/2017, s. 75-98

(c) $(1) \Theta$

MiŁOsz STĘPIŃSKI*

\section{Kompleks Olimpijski w Berlinie w 1933 roku - geneza koncepcje i cele. \\ Idea olimpijska w III Rzeszy w procesie stabilizacji reżymu narodowosocjalistycznego cz. 2}

\section{Olympic Stadium in Berlin 1933 - Genesis, concept and aims. The role of Olympic idea in the Third Reich in the process of Nazi regime stabilization Part 2.}

Streszczenie: Powstanie Kompleksu Olimpijskiego w Berlinie powszechnie wiązane jest z XI. Letnimi Igrzyskami Olimpijskimi, zorganizowanymi w nazistowskim Berlinie w dniach 1-16 sierpnia 1936 roku. W drugiej części artykułu opisano proces podejmowania decyzji dotyczących budowy, a w zasadzie rozbudowy Kompleksu Olimpijskiego. Przedstawiono działania osób odpowiedzialnych za ten proces oraz wpływ Adolfa Hitlera i Wernera Marcha na ostateczną wersję projektu obiektów. Oprócz tego przedstawiono harmonogram prac przygotowawczych, problemy finansowe i prawne, a także trudne neszczecin.pl.

Uniwersytet Szczeciński, ul. Mickiewicza 64, 71-101 Szczecin, mstepinski@univ. 
gocjacje z właścicielami, klubami sportowymi i organizacjami, które zarządzały terenami w dzielnicy Gruenewald, gdzie budowano stadion i przyległe do niego obiekty. Wszystkie te procesy odbywały się w specyficznej otoczce nazistowskiej propagandy, której wybrane przykłady opisano również w tekście.

Abstract: The construction of the Olympic Complex in Berlin is associated with XI. Summer Olympics, organized in Nazi Berlin on 1-16 August 1936. The second part of the article describes the decision-making process concerning the construction of the Olympic Complex. The activities of the persons responsible for this process and the influence of Adolf Hitler and Werner March on the final version of the project were presented. In addition, a timetable for the preparatory work, financial and legal issues involved, as well as difficult negotiations with owners, sports clubs and organizations managing the sites in the Gruenewald district, where the stadium was built, were presented. All these processes took place in a specific environment of Nazi propaganda, whose selected examples are also described in the text.

Słowa kluczowe: Igrzyska Olimpijskie, Sport w 3 Rzeszy

Keywords: Olympic games, Sport in third Reich

Dowstanie i istnienie po dziś dzień Kompleksu Olimpijskiego w Berlinie 1 związane jest z XI Letnimi Igrzyskami Olimpijskimi, zorganizowanymi w nazistowskim Berlinie w dniach 1-16 sierpnia 1936 roku. Mało kto jednak wie, że pierwszy stadion wybudowano w berlińskiej dzielnicy Grünewald z myślą o Igrzyskach, które miały się odbyć w Berlinie w 1916 roku. Imprezę z powodu przedłużającej się Wielkiej Wojny ostatecznie odwołano, ale obiekt olimpijski, tzw. Stadion Niemiecki powstał. Przygotowując się w latach trzydziestych do Igrzysk w 1936 roku początkowo nikt nie zakładał tak rewolucyjnych zmian $w$ architekturze olimpijsko-sportowej Grünewald. Każdy był przekonany, że wszelkie zmiany dotyczyć będą przebudowy Stadionu Niemieckiego, z zachowaniem jego „wilhelmińskiego" klimatu, rozbudowy Forum Sportu i budowy kilku mniejszych obiektów, m.in. pływalni. Nikt z zebranych, wiernych paladynów Hitlera, nie brał pod uwagę rozebrania i postawienia praktycznie od nowa całego stadionu. Nie doceniano determinacji i wizjonerstwa Führera. Jak napisali Hajo Bernett i Hans-Joachim Teichler, w 1933 roku Komitet Organizacyjny opierał się na założeniu Theodora Lewalda z 16 marca tego roku, mówią- 
cego jedynie o rozbudowie Stadionu Niemieckiego, które miało się odbyć kosztem 3,5 mln $\mathrm{mk}^{1}$. W lipcu suma skoczyła już do 5,460 mln $\mathrm{mk}$, co może świadczyć o tym, że na tym etapie Hitler i March wprowadzili już swoje „poprawki”. Wizyta Fuhrera na Stadionie 5 października 1933 roku zapoczątkowała prawdziwą rewolucję na terenie przyszłego Kompleksu Olimpijskiego, jednakże o tym za chwilę.

W dniu 27 lipca 1933 roku Carl Diem poinformował sekretarza stanu, że Wydział Budowlany określił koszty rozbudowy Stadionu i Forum Sportu następująco: do 31 marca 1934 roku - 2 mln mk.; do 31 października 1934 roku - 3,4 mln mk. (z czego milion mk pochłonąć miało dokończenie Forum Sportu, a 2,4 mln mk - prace na Stadionie). Wydział podkreślał też konieczność przyspieszenia prac w Forum Sportu, by dotychczasowi użytkownicy Stadionu mogli być jak najszybciej przeniesieni do Forum, a sportowcy nie stracili możliwości kontynuacji treningu ${ }^{2}$.

Werner March zetknął się z „Nowym Budownictwem”, cechującym się połączeniem nowoczesnych zasad konstrukcji z klasycznymi poprzez projekt Niemieckiego Forum Sportowego ${ }^{3}$. Jego projekty nowego Stadionu Olimpijskiego pozostawały silnie pod wpływem nowoczesnego pojmowania architektury.

$\mathrm{Na}$ dzień 16 sierpnia 1933 roku, zaplanowano posiedzenie, na którym miano ostatecznie wyjaśnić sprawy własnościowe na terenie przyszłego Kompleksu Olimpijskiego. W spotkaniu brali udział: sekretarz stanu Hans Pfundner, minister Finansów Rzeszy, pruscy ministrowie finansów i rolnictwa, nadburmistrz m. Berlina, przewodniczący Niemieckiego Towarzystwa Prac Publicznych i Kierownik Urzędu Sportu Rzeszy. Na spotkaniu stara-

${ }^{1}$ H. Bernett. H.-J. Teichler, Olympia unter dem Hakenkreuz, Deutschland in der Olympischen Bewegung. Eine Zwischenbilanz, Hrsg. Nationales Olympisches Komitee für Deutschland, Frankfurt/Main 1999, s. 132.

${ }^{2}$ BA, 1501, Nr. 5608 f. 93-93a.

3 W latach 1926-1933 wykonano cześć obiektów Niemieckiego Forum Sportu: min. halę gimnastyczną i korty tenisowe (1928 r.). W latach 1935/36 rozpoczęła się druga część rozbudowy, obejmująca m.in. budowę imponującego Domu Niemieckiego Sportu. Do tematu: Das Deutsche Sportforum. Im Auftrage des Deutschen Reichskomitees fur Leibeubungen, verfasst von Gerhard Krause, Berlin 1925, s. 49-52, 76-81; także R. Mandell The Nazi Olympics. New York, s. 240. 
no się również ostatecznie wyjaśnić inne kwestie, mianowicie: czy Rzesza sama czy razem z miastem Berlinem będzie płacić za prace na stadionie? Czy środki finansowe na rozbudowę Forum Sportowego mają pochodzić z pożyczki? Czy możliwe jest przeniesienie praw własności terenu Stadionu i Forum z Prus na Rzeszę lub miasto Berlin? W toku rozmów ustalono, że finansowanie rozbudowy Forum Sportu w kwocie 1,4 mln mk przejmie sama Rzesza, ponieważ po rozwiązaniu Niemieckiego Komitetu Rzeszy ds. Ćwiczeń Cielesnych (dalej NKRCC) jego dobra i zobowiązania przeszły na nią, w tym m.in. umowa dzierżawy terenu Kompleksu zawiązana z Prusami. Zakładano, że prace budowlane na Stadionie Olimpijskim, włącznie z budową pływalni, wyceniane na $4 \mathrm{mln}$ mk zrealizuje miasto Berlin wspólnie z Rzeszą .

Wydarzeniem przełomowym dla ostatecznego architektonicznego ukształtowania przyszłego Kompleksu Olimpijskiego była wizyta samego Hitlera w dniu 5 października 1933 roku na „starym” Stadionie Olimpijskim $^{5}$. Kanclerzowi towarzyszyli: minister spraw wewnętrznych - Hans Frick, sekretarz stanu Hans Pfundtner, wszyscy członkowie Komisji Budowlanej, W. March z bratem i kierownik Urzędu Sportu Rzeszy. Ten ostatni oprowadził kanclerza po wszystkich obiektach. W wielkiej hali turnerskiej Hitler zagłębił się w szczegóły modeli Forum Sportu i Stadionu Olimpijskiego. Jak opisał to Lewald w notatce z adnotacją „Poufne!” z tegoż samego dnia: „Kanclerz, z właściwym sobie zamiłowaniem do architektury, okazał wszystkim kwestiom największe zainteresowanie i rozpoznawał z właściwą sobie przenikliwością myśli i plany zebranych" ${ }^{6}$. Otoczenie kanclerza musiał ogarnąć entuzjazm, po tym jak zorientowali się, że Hitler zdecydował się nie oszczędzać na budowie Kompleksu Olimpijskiego. Przykładem może być przywrócenie do planu budowy Forum Sportu, które wypadło z niego ze względów oszczędnościowych. Później wszystkie pomysły, jakie Lewald, Diem i March prezentowali mu jako godne wykonania, ale

${ }^{4}$ BABL, 1501 Nr. 5608 f. 111-115, Vermerk.

${ }^{5}$ H. Bernett, H. J. Teichler, Olympia, s. 133. Słynne zdjęcie, ukazujące rozpromienionego Hiltera w rozmowie z Ministrem Spraw Wewnętrznych Rzeszy, H. Frickiem podczas wizyty na Niemieckim Stadionie.

${ }^{6}$ BABL, Rep. 1501 Nr. 5086 s. 171, Aufzeichnung. Vertraulich!, gez. Lewald, den 5. Okt. 1933. 
nieosiągalne, zyskały nagle status „do wykonania”. Fuhrer zdecydował też o przeniesieniu Toru Wyścigowego z obrębu Stadionu na nową - osobną lokalizację.

Podczas zwiedzania Forum Sportu W. March usłyszał to, czego on i inni oczekiwali - ambicje kanclerza szły w kierunku nadania obiektom imponujących i reprezentacyjnych rozmiarów, odpowiadających wadze wydarzenia, jakim były Igrzyska. Sporządzający protokół tego historycznego spotkania Th. Lewald pisat ${ }^{7}$ :

Zwróciłem Fuhrerowi uwagę, że Stadion jest nie tylko obiektem sportowym, ale może być również wykorzystany do celów ogólnopolitycznych. Wspomniałem przy tym, że miasto czyni trudności z powodu jeszcze nie wyjaśnionych problemów prawnych. Kanclerz odpart, że Stadion musi być zbudowany od nowa i to jest zadanie całej Rzeszy. Jeżeli zaprasza się cały świat, to musi powstać coś wspaniałego i pięknego.

Rozmach inwestycyjny Hitlera uwidocznił się również podczas wyboru materiałów budowlanych. Gdy W. March pokazał mu różne rodzaje kamienia, Fuhrer wybrał drogi kamień wydobywany w Niemczech dodając, że jeśli ma się $4 \mathrm{mln}$ bezrobotnych, to trzeba dać im pracę, a kilka milionów dodatkowych marek nie gra żadnej roli. Zażądał od W. Marcha, aby pojawił się u niego na początku następnego tygodnia z całością planów. Nalegał, by po ich zatwierdzeniu niezwłocznie przystąpić do prac budowlanych. Th. Lewald, starając się przymilić Hitlerowi, zapytywał za pośrednictwem Wilhelma Fricka, czy kanclerz byłby gotów dokonać symbolicznego „pierwszego wbicia łopaty”. Co ciekawe, Hitler odrzucił ten pomysł jako zbyteczny. Th. Lewald, w swoich notatkach z zadowoleniem odnotowywał wspomniany rozmach Hitlera, co stanowiło spełnienie jego marzeń ${ }^{8}$. Hitler w dniu 5 października 1933 roku dostrzegł szansę ukazania światu, poprzez

7 BABL, Rep.1501 Nr. 5086 s. 173, Aufzeichnung. Vertraulich!, gez. Lewald, den 5. Okt. 1933. „Kanclerz oświadczył, że Stadion musi być zbudowany od nowa przez Rzeszę. Jeżeli cały świat zaprosiło się w gości, to trzeba stworzyć coś wspaniałego i pięknego".

${ }^{8}$ BABL, Rep. 1501 Nr. 5068 f. 17. Aufzeichnung. Vertraulich!, gez. Lewald, den 5. Okt. 1933: „Jest pewne, że kanclerz będzie chciał, by Stadion Olimpijski wybudowała Rzesza. Tą decyzję należy powitać z największą wdzięcznością i radością. [...]. Wierzę, że dziś zrobiono decydujący krok w kierunku urzeczywistnienia naszych nadziei i planów”. 
budowę okazałego Kompleksu Olimpijskiego, siły i wielkości III Rzeszy. „Chcemy budować!”, brzmiały słowa Fuhrera, które propaganda poniosła w świat. Uważający się za znawcę architektury Hitler, domagał sie od W. Marcha, przedstawienia nowej koncepcji, tym samym odbierając Komitetowi Organizacyjnemu Igrzysk kompetencje w zakresie projektowania obiektów olimpijskich?. Jak napisał Wiulhelm Schnauk w czasopiśmie, poświęconym kulturze fizycznej, z jesieni 1936 roku: „Stadion Niemiecki z bieżnią o długości $600 \mathrm{~m}$ i miejscami dla 30000 osób, w konfrontacji z wolą dyktatora, wzbudzenia w świecie podziwu dla <olimpijskich obiektów sportowych w Stolicy Rzeszy>, przegrywał z kretesem i powinien zostać po prostu wysadzony, ustępując miejsca celom sportowym i ideologicznym reżymu"10.

Wizja Hitlera z 5 października 1933 roku, zaprezentowania światu sportowej stolicy Rzeszy, była intensywnie eksponowana propagandowo w Niemczech i na zewnątrz ${ }^{11}$. Entuzjazm Hitlera przyspieszył rozwiązywanie kwestii kształtu architektonicznego terenów olimpijskich, jak i ich statusu własnościowego. Thomas Alkmeyer stwierdził, że przestrzenne urządzenie było jednym z najważniejszych pól produkcji symboli/znaków i strategii zarządzania masami w Igrzyskach 1936 roku. Kompleks Olimpijski w Berlinie był pierwszym, wielkim projektem architektonicznym III Rzeszy. Państwo zażądało istotnych korektur projektów, kierując je w stronę wielkości i monumentalności. W ten sposób powstało dzieło

${ }^{9}$ H. Bernett, H.-J. Teichler, Olympia, s. 133. W dniu 10 października 1933 r. Hitler w towarzystwie Goebbelsa, Fricka i Pfundtnera postanowili powierzyć W. Marchowi budowę Stadionu Olimpijskiego.

${ }_{10}$ W. Schnauk, Wie die olympischen Kampfstätten wurden, w: Leibesübungen und körperliche Erziehung, Heft 15/16, s. 421.

${ }^{11}$ Świat dowiedział się o decydującej roli Hitlera w projektowaniu Kompleksu Olimpijskiego m.in. z oficjalnego sprawozdania pt. XI. Olympiade Berlin 1936-Amtlicher Bericht. Band I, Herausgeben vom Organisationskommitee für die XI. Olympiade Berlin 1936. e.V., s. 54-57. Jest to wielostronicowa publikacja (1 220 stron), wydana po Igrzyskach w setkach tysięcy egzemplarzy, w języku niemieckim i angielskim, wysłana do wielu krajów z całego świata. Na s. 56 znajduje się „stary” plan przebudowy Stadionu Olimpijskiego z początków 1933 r. 
(Kompleks) potwierdzające mit nowo pobudzonych zdolności twórczych Niemiec pod wodzą Hitlera ${ }^{12}$.

Wizja Hitlera skłoniła do aktywniejszego działania H. Pfundtnera, który do gmachu Ministerstwa Spraw Wewnętrznych zaprosił działaczy reprezentujących Towarzystwo Jeździeckie. H. Pfundtner oświadczył, że rząd Rzeszy chce budować imponujące budowle sportowe na terenie Grünewaldu, by zabezpieczyć niemieckiemu sportowi odpowiednie zewnętrzne ramy dla wystąpienia przed światem podczas Igrzysk XI Olimpiady. W tym celu niezbędne jest przejęcie całego terenu Toru Jeździeckiego na. Grünewaldzie Pozostawało pytanie, pod jakimi warunkami Towarzystwo jest skłonne opuścić ten teren? Pfundtner podkreślił, że Kanclerz jest daleki od tego, by sport jeździecki ucierpiał w jakikolwiek sposób na przeprowadzce ${ }^{13}$.

W tym miejscu przypomnijmy, że propaganda - także później - podkreślała ogromną determinację kanclerza w nadaniu obiektowi na Gruenewaldzie piętna nowoczesności i symbolu wiodących międzynarodowych standardów. Przykładem może być właśnie wyburzenie „starego Stadionu” i budowa zupełnie nowego obiektu. Erich Mindt zaprezentował idee Fuhrera następująco ${ }^{14}$ :

Przygotowania do tych Igrzysk są w pełnym biegu. Poza ogromnymi pracami organizacyjnymi, dzięki inicjatywom naszego Wodza, zostaną wzniesione ogromne budowle sportowe. Tym samym obiekty zmagań w Berlińskim Grünewaldzie otrzymają nową szatę. Stary, jakże nam drogi Stadion Niemiecki w Berlinie musiał ustąpić miejsca nowym imponującym planom. W Garmisch-Partenkirchen budowana jest m.in. Olimpijska Skoczna i wielki Stadion do jazdy na lodzie.

Dzień 5 października można uznać za przełomowy. Wtedy to zrodziła się idea budowy imponującego Kompleksu Olimpijskiego. Oprócz Forum Sportu miały powstać również m.in. „Dom Niemieckiego Sportu” i nowe obiekty Wyższej Szkoły (Akademii Rzeszy) Ćwiczeń Cielesnych. Wszystko

12 Th. Alkmeyer, Körper-und Einbildungskraft, s. 47.

13 BABL, Rep., 1501 Nr. 5068 f. 187.

${ }^{14}$ OLYMPIA 1936. Eine nationale Aufgabe. Lichtbilder-Vortrag in 40 Bildern, bearbeitet von Erich Mindt, Berlin, [brak daty wydania - 1934?], s. 10. 
to w jednym miejscu miało przedstawić gościom podczas Igrzysk Olimpijskich wzorcowy przykład narodowego centrum sportu. Dla spraw sportu Hitler miał mało zrozumienia. Bardziej zależało mu na zaimponowaniu światu „wolą budowania” i wprowadzeniem do infrastruktury sportowej politycznych aspektów ${ }^{15}$.

Wracając do rokowań Towarzystwa Jeździeckiego z Ministerstwem Spraw Wewnętrznych, należy podkreślić, że jak zawsze chodziło o pieniądze. Miłośnicy jazdy konnej zainwestowali w ten teren ogromne sumy. Sam tor kosztował 4,7 mln. mk, utrzymanie Stadionu dalsze 1,7 $\mathrm{mln}$ mk. Opuszczenie toru byłoby „niesłychanym ciosem” dla Towarzystwa Jeździeckiego ${ }^{16}$. Prundtner odpowiedział, że kanclerz nie zamyka się na te argumenty i stara się znaleźć kompromis. W piśmie z 17 października prezydium Towarzystwa Jeździeckiego powtórzyło swoje roszczenia wobec państwa i przypomniało skalę poniesionych na Grünewaldzie wydatków. Występujący w roli dzierżawcy Toru - Klub Union - określił swoje dotychczasowe wydatki na Torze i Stadionie na 7692780 mk i choć rezygnacja z Toru w Grünewaldzie oznaczała dla niego „ciężką stratę”, to Klub Union, w „interesie narodowej sprawy”, był skłonny - zgodnie z życzeniem kanclerza Rzeszy - zrezygnować z dzierżawy trwającej jeszcze 10 lat. Warunkiem było przekazanie Berlińskiemu Związkowi Jeździeckiemu odszkodowania w wysokości $2,75 \mathrm{mln}$ mk, a także przejęcie przez Rzeszę zobowiązań Towarzystwa Jeździeckiego wobec kilku instytucji, m.in. Pruskich Lasów Państwowych.

Wpływ decyzji Hitlera na kształt Kompleksu nie ograniczał się wyłącznie do spraw zasadniczych. Fuhrer ingerował również w sprawy mniej istotne, takie jak np. odrzucenie przejętych z funkcjonalizmu oszklonych widocznych betonowych nadbudów, zstępując je naturalnym kamieniem ${ }^{17}$.

${ }^{15}$ H. Bernett, H.-J. Teichler, Olympia, s. 133-134. Nieco później Hitler pochylił się nad planami W. Marcha i osobiście wyznaczył po zachodniej stronie Stadionu plac, który uznał za dostatecznie duży na organizowanie świąt i manifestacji.

${ }^{16}$ BABL, Rep., 1501 Nr. 5068 f. 188. Rotmistrz Krause nazwał opuszczenie Toru za „śmiertelny” cios dla berlińskiego jeździectwa. Przypomniał o organizowanych tam międzynarodowych gonitwach i światowej renomie obiektu. Podobno był przez zagranicznych gości nazywany najpiękniejszym torem świata.

${ }^{17}$ Th. Alkmeyer, Gewalt und Opfer, s, 47. 
Pierwsze ingerencje w stare plany zabudowy były drobne i szybko okazało się, że daleko niewystarczające. Ostatecznie postawiono na zupełnie nowy projekt. W ten sposób doszło do powstania pierwszego wielkiego sportowego projektu narodowego socjalizmu, którego planowanie i realizacja stały się wzorcem dla wszystkich późniejszych przedsięwzięć. Tendencją było koncentrowanie wydarzeń sportowych na jednym dużym kompleksie ${ }^{18}$.

To oddziaływanie wizji Hitlera na W. Marcha, uwidoczniło się przy kontroli dokumentów finansowych. Porównanie liczby obiektów w kosztorysie W. Marcha z 26 lipca 1936 roku i tegoż samego kosztorysu sporządzonego 18 października 1933 roku u H. Pfundtnera ukazywało dynamikę zmian. W drugim pojawiły się: Stadion Kolarski, Stadion Tenisowy i tzw. „ogromny teren manifestacji” (później nazwany Polem Marsowym). U W. Marcha „Stadion Główny” (wraz z pracami rozbiórkowymi Stadionu Niemieckiego) miał kosztować 925 tys. mk. W myśl propozycji z 18 października, po powiększeniu obiektu do 100 tys. widzów - koszty wynosiły już 3,5 mln mk. Niewymieniony w pierwszym planie W. Marcha, wielki Amfiteatr im. Dietricha Eckhardtsa - miał kosztować 900 tys. mk. Drugim najdroższym obiektem (po Stadionie) w kosztorysie miał być „wielki teren na manifestacje” (ok. $2 \mathrm{mln} \mathrm{mk}$ ). Całość zamykała się w astronomicznej kwocie 8-8,5 mln $\mathrm{mk}^{19}$. Kompleks Olimpijski, według nowych planów łączył zdaniem Hitlera cele sportowe z politycznymi; interesy nazistowskiej masowej reżyserii spleciono z doniosłością sportu olimpijskiego. Przykładem może być „Pole Majowe” - ogromny teren na zachodnim przedłużeniu stadionu przeznaczony na przyszłe manifestacje i defilady, które mogłoby oglądać nawet 250 tys. osób. Obok „pola” miała się znajdować monumentalna Wieża Dzwonu. Międzynarodowy Komitet Olimpijski ( dalej MKOl) zaakceptował nowe plany Kompleksu. Tak więc Kompleks Olimpijski za-

${ }^{18}$ F.J. Vespohl, Das Reichsportfeld, s. 29; szczegółowy opis poszczególnych elementów infrastruktury stadionu i danych technicznych po jego zbudowaniu. m.in.: Das Deutsche Stadion, Völkischer Beobachter. Nationalsozialistisches Kampfblatt fur Grossdeutschland, 206 Ausg. 49. Jg., 24. Juli 1936, Hans Pfundter, wówczas przewodniczący Komitetu Budownictwa, Sztuki i Święta XI Igrzysk Olimpijskich miał wykład w radiu niemieckim i w zagranicznych radiostacjach nt. Stadionu Olimpijskiego.

${ }^{19}$ BABL, 1501 Nr 5608 f. 231. Vermerk über die Besprechung vom 18. Oktober 1933 im Reichsministerium des Innern. 
planowano w osi Wschód-Zachód ${ }^{20}$. Propagandowe wydawnictwa olimpijskie o Kompleksie Olimpijskim, jak np. „Kompleks Olimpijski. Dzieło Trzeciej Rzeszy dla Igrzysk Olimpijskich i niemieckich ćwiczeń cielesnych”, wydane przez Ministerstwo Spraw Wewnętrznych Rzeszy, nie pozostawiały złudzeń, co do propagandowo-politycznej roli Pola Majowego, położonego celowo na jednej osi ze Stadionem Olimpijskim i Bramą Maratońską ${ }^{21}$.

Konflikt między państwem a grupą wpływowych środowisk klas wyższych, (świata cesarsko-weimarskiej arystokracji), skupioną w sportach jeździeckich Berlina został rozwiązany po ich myśli. Rząd nie był zainteresowany zaostrzaniem stosunków z Towarzystwem Jeździeckim i Klubem Union. Jeździectwo miało angielski rodowód i zupełnie nie mieściło się w tradycji sportów niemieckiej skrajnej prawicy, a już na pewno nie drobnomieszczańskich - w większości - członków Narodowosocjalistycznej Niemieckiej Partii Robotników (NSDAP). Pfundtner - niewątpliwie pod wpływem Hitlera - wywierał na miłośników jazdy konnej pośrednią presję poprzez nabierającą tempa propagandę olimpijską. Państwo cały czas chciało uniknąć wrażenia, jakoby było przeciwnikiem sportu jeździeckiego, który należał do tradycji i pasji klas wyższych i sfer oficerskich Rzeszy 22 .

Pierwsze wyliczenia dotyczące budowanych i przebudowywanych obiektów olimpijskich, pojawiły się w szacunkach W. Marcha dla Ministerstwa Spraw Wewnętrznych 23 października 1933 roku i wskazywały konieczność powiększenia areału w stosunku do pierwotnego niemal o połowę ${ }^{23}$. Jeśli chodzi o koszty, Pfundtner oceniał je na $6,5 \mathrm{mln}$ mk oraz 2,7 mln mk odszkodowania dla Towarzystwa Jeździeckiego. Miał przy tym

${ }^{20}$ H. Bernet, H.-J. Teichler, Olympia, s. 134. Przypominają, że Amfiteatr na 20 tys. miejsc nazwano imieniem literackiego bojownika narodowego socjalizmu; Współcześnie m.in. W. Schluter, Von Athen nach Berlin, Berlin 1936, s. 20, 22-23, 25, tamże: plan Kompleksu Olimpijskiego; H. Bernett, H.J. Teichler, Olympia, s. 134.

${ }^{21}$ W. March, Die baukünstlerische Gestaltung des Rechssportfeldes, w: Das Reichssportfeld. Eine Schöpfung des Dritten Reiches für die Olympischen Spiele und die Deutschen Leibesübungen, Herausgegeben vom Reichsministerium des Innern, Berlin 1936, s. $40-41$.

${ }^{22}$ H. Eichberg, Sport im 19. Jahrhundert-Genese einer industriellen Verhaltensform, w: Geschichte der Leibesübungen, Teilb. 1. s. 360-362.

${ }^{23}$ BABL, Rep. 1501 Nr. 5608 s. 225-226. Podział ten był następujący: teren jeździecki w Berlinie-, Grünewald Niemieckie Forum Sportu i północne uzupełnienie 
nadzieję na znaczne obniżenie tej drugiej sumy. Chcąc wykonać wszystko na czas, prace budowlane powinny się zacząć najpóźniej 30 października 1933 roku. Liczono się z jeszcze wyższymi niż 18 października wydatkami. W kosztorysie W. Marcha z 24 października 1933 roku koszty budowy wszystkich obiektów olimpijskich wyliczano na $9 \mathrm{mln} \mathrm{mk,} \mathrm{z} \mathrm{czego} \mathrm{najwię-}$ cej, bo aż 3,5 mln mk miała pochłonąć budowa „Stadionu Olimpijskiego na 100 tys. miejsc ${ }^{24 "}$. Natomiast koszty planowanych budynków, przeznaczonych dla zakończenia budowy Niemieckiego Forum Sportu, miały wynieść 4,695 mln $\mathrm{mk}^{25}$.

Zakończenie budowy niektórych budynków planowano jeszcze w 1934 roku, podobnie jak wzniesienie stadionu do stanu „surowego”. Ukończenie stadionu planowano dopiero na jesień 1935 roku $^{26}$. March dodawał, że dalsze koszty obejmą: zburzenie Toru Jeździeckiego i dolnych miejsc stojących starego stadionu oraz pogłębienie jego wnętrza - w sumie 450 tys. mk.

Warto podkreślić, iż na przełomie października i listopada 1933 roku infrastruktura Forum Sportu uległa na papierze dalszej rozbudowie, a jego koszty znacząco wzrosły. W notatce Pfundnera z 14 listopada 1933 roku można przeczytać, że po naradzie Hitlera z W. Marchem i „Reichssportführerem” znaczącej rozbudowie miało ulec Forum Sportu i tym samym

Forum Sportu $=85,87$ ha, infrastruktura drogowa i parkingowa $=45,7$ ha $[$ głównie Amfiteatr - 8,61 ha]. Ogółem = ogółem 131,61 ha.

${ }^{24}$ BABL, Rep. 1501 Nr. 5608 s. 231-232. Pismo W. Marcha do H. Pfundtnera. Dalsze pod względem kosztów obiekty to „tereny manifestacji” - 2,000,000 mk i Amfiteatr-1.000.000 mk.

${ }^{25}$ BABL, Rep. 1501 Nr. 5608 s. 233-235. K o s t e n u b e r s c h l a g u n g für die noch zu errichtenden Gebäude zum endgültigen Ausbau des Deutschen Sportforums in Berlin-Grünewald. [ 24.Oktober 1933 ]. Notatka H. Pfundtnera z 11 listopada 1933 r. Chodziło o Dom Niemieckiego Sportu, Hale Gimnastyczną i Pływalnię.

${ }^{26}$ Należy zauważyć, że podniesiony wyżej przełom w wizji Stadionu Olimpijskiego z 5 października 1933 r. znalazł swój wyraz również po stronie kosztów. Jeśli NKRzCC [ Th. Lewald ] w lipcu 1933 r. szacował koszty przebudowy wnętrza Stadionu na 1.759 .315 mk, to w końcu października mówiono już o 5.500 .000 mk, a w końcu listopada 1933 r. 8.500.000 mk. Stosunkowo stabilne pozostawały koszty Stadionu Pływackiego, które kształtowały się odpowiednio w lipcu - 461.304 mk, w październiku i listopadzie 500.000 $\mathrm{mk}$. 
wzrosnąć jego koszty. Razem z rozbudową ulic koszty miały wynieść ok. $19 \mathrm{mln}$ mk, w tym: Stadion Olimpijski 8,5 mln mk, Forum Sportu 6,5 mln mk [tutaj budowa także Domu Noclegowego i Instytutu Medyczne-

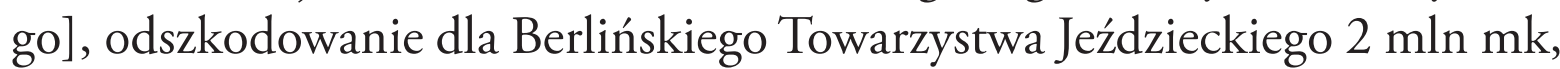
pozyskanie terenu od Pruskiego Fiskusa milion mk i budowa ulic w obrębie Stadionu i Forum Sportu milion $\mathrm{mk}^{27}$. Roszczenia finansowe hr. Spreti i Towarzystwa Jeździeckiego silnie zaprzątały uwagę Pfundtnera i zapewne samego Hitlera. W piśmie do prezydium Towarzystwa z 24 października 1933 roku sekretarz stanu wyraził wątpliwości, czy Rzesza będzie w stanie wypłacić 750 tys. mk na pokrycie długu wobec Klubu Union, jak i dalsze $2 \mathrm{mln}$ mk dla Klubu Union i dla Towarzystwa Gonitw z Przeszkodami jako odszkodowania za przeniesienie na Tory w Karlhorst i Hoppengarten. Sekretarz stwierdzał, że Kanclerz przewiduje wydatkowanie znacznych sum w ramach Olimpiady wyłącznie na prace publiczne. Dlatego też „najuprzejmiej” prosił o jak najszybsze określenie rzeczywistych kosztów ${ }^{28}$.

Wszystkie dalsze rozmowy ze światem hippiki i pruskim fiskusem przebiegały pod wpływem wielkich, architektonicznych wizji Hitlera. H. Pfundtner często operował argumentem „woli kanclerza stworzenia imponującego Kompleksu”. Tego argumentu używał m.in. w rozmowach z Ministerstwem Wyżywienia Rzeszy na temat pozyskania od Pruskich Lasów Państwowych całego terenu na Grünewaldzie. Uzyskanie tego terenu było warunkiem, aby Hitler miał wolną rękę w realizacji swoich planów budowy Kompleksu Olimpijskiego. Lektura notatki H. Pfundtnera z 14 listopada 1933 roku wskazuje, że jego zabiegi wobec Prus, a personalnie Hermanna Goeriga jako premiera Prus, szły w tym kierunku, by uzyskać te tereny za darmo lub za możliwie niską cenę. Pruskie Lasy Państwowe wyceniły wartość tego terenu (130 ha) na $5 \mathrm{mk}$ za 1 ha, co dawało sumę $6 \mathrm{mln}$

${ }^{27}$ BABL, Rep. 1501 Nr. 5608 f. 285. Vermerk über die Vorbereitung der Bauten am Sportforum und Stadion. W liście H. Pfundtnera do ministra finansów Rzeszy z 16 listopada 1933 r. na temat finansowania wszystkich obiektów olimpijskich, w tym także Toru Wioślarskiego w Berlinie Grunau, jest mowa także o „wielkim” budynku Administracji i Dydaktyki na Forum Sportu [ibidem, s. 295].

${ }^{28}$ BABL,Rep. 1501 Nr. 5608 f. 237-241. Najpewniej dla wywarcia nacisku na Towarzystwo H. Pfundtner zamieścił wspomniany kosztorys rozbudowy Forum Sportu W. Marcha, sugerujący wielką skalę wydatków, jakie czekały Rzeszę. 
mk. Premier Hans Goering wyraził gotowość rezygnacji Prus z tego terenu, jeśli Rzesza odstąpi Prusom pozyskane w ramach Osthilfe lasy o wartości 3 mln mk. Tymczasem H. Pfundtner naciskał na H. Goeringa, aby Prusy oddały teren Fuhrerowi za darmo lub obniżyły cenę 1 ha do 50-75 fenigów, co pozwoliłoby Rzeszy pozyskać ten teren za ok. milio $\mathrm{mk}^{29}$. Premier Prus, H. Goering zgodził się na to rozwiązanie. Dnia 27 grudnia została zawarta umowa między Rzeszą i Prusami, a trzy dni później teren został przekazany Rzeszy ${ }^{30}$.

Świat berlińskiej hippiki nie dawał za wygraną i wydawał się być niewzruszony patriotycznymi argumentami Ministerstwa Spraw Wewnętrznych. W pismach z 17 i 27 marca opisywali swoje warunki opuszczenia Grünewaldu: 1) spłata długu w kwocie 750 tys. mk, jaki miało Towarzystwo Jeździeckie wobec Klubu Union, 2) dotacja w wysokości 930 tys. mk i 700 tys. mk na rozbudowę torów jeździeckich w Karlshorst i Hoppegarten. W sumie dawało to $2,35 \mathrm{mln}$ mk. Ponadto Towarzystwo Jeździeckie pisało o $6 \mathrm{mln} \mathrm{mk}$, jakie wydało dotąd na Tor Jeździecki ${ }^{31}$. Na listopadowym spotkaniu hr. Spretti, „dorzucił” jeszcze do tych sum 50 tys. mk na rozbudowę trybun i bieżni w Hoppengarten, a także 300 tys. mk na sfinansowanie nagród w gonitwach. H. Pfundtner był gotów w imieniu

${ }^{29}$ BABL,Rep. 1501 Nr. 5608 f. 281 i 283. W tym dokumencie, bodaj po raz pierwszy, pada suma ogólnych kosztów przedsięwzięcia - 19 mln mk [ f. 287],

${ }^{30}$ H. Pfundtner, Die Gesamtleitung der Errichtung des Reichssportfeldes, w: Das Reichssportfeld, s. 15: Tym samym państwo pruskie „we wspaniałomyślny sposób” wsparło plany Führera budowy Kompleksu Olimpijskiego. BABL, Rep., 1501 Nr. 5609, f. 13, pismem z 4 grudnia 1936 r. minister spraw wewnętrznych Rzeszy, H. Frick dziękował H. Goeringowi za przyjęcie „okrągłej ceny” $1 \mathrm{mln}$ mk za teren, [o powierzchni 131 ha M.S.], potrzebny Rzeszy dla rozszerzenia Stadionu i Forum Sportu, stwierdzając: „'Tym samym zostały stworzone podstawy dla planowanego rozszerzenia Forum Sportu i Stadionu i dla wyrażonego przez pana kanclerza Rzeszy życzenia, aby doszło do wspaniałej realizacji XI Olimpiady, tak ważnej dla podkreślenia światowego znaczenia Niemiec”.

${ }^{31}$ BABL,Rep. 1501 Nr, 5608 f. 275. Vermerk über die Besprechung vom 7. November 1933 mit dem Präsidium des Berliner Rennvereins, Berlin, 11. November 1933. Słowa sekretarza stanu ze spotkania z 11 listopada: „Należy podkreślić, że zdaniem elity jeździeckiego Berlina apetyty Rzeszy na Grünewald kończyły tradycję wielkich, klasycznych gonitw, jak Wielka Nagroda Berlina”. 
Państwa pokryć długi Towarzystwa wobec Klubu Union oraz wypłacić obu towarzystwom jedynie 1-1,25 mln mk.

Jak już wspomniano, Hitlerowi zależało jeszcze wtedy na ugodzie z uprawiającymi jeździectwo elitami Berlina i Prus, skupionymi w towarzystwach hippicznych na Grünewaldzie, co wyrażało się tym, że począwszy od połowy listopada 1933 roku H. Pfundtner wzmógł naciski na Ministerstwo Finansów Rzeszy, by zaspokoiło roszczenia Prus i kół jeździeckich. Był też pod presją czasu, wynikającą z harmonogramu prac i niemal gotowych już planów architektonicznych W. Marcha. W piśmie z 16 listopada do tegoż ministerstwa ponownie użył argumentu „woli Fuhrera”: „Kanclerz Rzeszy, mając na celu silne wspieranie całego niemieckiego sportu, z uwagi na mające miejsce w 1936 roku w Berlinie Igrzyska, zdecydował o rozbudowie Stadionu i Niemieckiego Forum Sportu na Gruenewaldzie" 32 . Opisywał podniesione już wyżej starania o przejęcie przez Rzeszę tego obszaru od Pruskich Lasów Państwowych i finansowych warunkach, stawianych przez H. Goeringa. W kwestii odszkodowania dla towarzystw jeździeckich determinacja H. Fricka i H. Pfundtnera z 7 listopada, aby wypłacić im jedynie milion mk, znacząco zelżała. W piśmie z 18 listopada czytamy już o 1,75 mln mk jako pełnym odszkodowaniu, uwzględniającym także pozostawioną przez Towarzystwo Jeździeckie na Grünewaldzie wartościową infrastrukturę. Sekretarz stanu uznał tę sumę za możliwą do przeforsowania w negocjacjach z jeźdźcami i prosił resort finansów o tę kwotę.

W kwestii kosztów budowy przyszłego Kompleksu Olimpijskiego, Frick informował resort finansów, że koszty całych przygotowań olimpijskich wyceniał na niemal $20 \mathrm{mln} \mathrm{mk}^{33}$.

Omawiane powyżej tematy wróciły podczas spotkania wysokich urzędników obu resortów 21 listopada oraz liście Fricka do resortu finan-

32 BABL, 1501 Nr. 5068 f. 295, list Ministra Spraw Wewnętrznych Rzeszy do Ministra Finansów Rzeszy z 16 listopada 1933 r. całość: f. 295-305. Przypominał o budynkach, wymienionych już w kosztorysie W. Marcha z 24 pażdziernika1933 r. List w imieniu H. Fricka podpisał H. Pfundtner.

${ }^{33}$ BABL, Rep. 1501 Nr. 5068 f. 302. W piśmie W. Marcha do Pfundtnera z 24 października 1933 r. na temat ogólnych kosztów Kompleksu Olimpijskiego [bez Forum Sportu], pojawiła się nowa pozycja - „Stadion Tenisowy” na 10 tys. miejsc za 300 tys. mk. [idem, f. 231]. 
sów nadanym dwa dni później. Podczas spotkania stwierdzono stanowczo, że „Rzesza potrzebuje pilnie terenu na Grünewaldzie, gdzie mają być wzniesione ogromne budowle". Przedstawicieli Ministerstwa Finansów naciskano, aby z żądań towarzystw hippicznych najpilniej został pokryty dług 750 tys. mk, jaki Berlińskie Towarzystwo Jeździeckie było winne Klubowi Union.

W początku grudnia 1933 roku $\mathrm{H}$. Pfundtner uznał, że projekt budynków na Igrzyska XI Olimpiady jest tak zaawansowany, że mógł zostać przedstawiony Hitlerowi przez Ministerstwo Spraw Wewnętrznych w porozumieniu $\mathrm{z}$ innymi instytucjami, co planowano połączyć z prezentacją nowego, gotowego modelu Kompleksu Olimpijskiego przez W. Marcha. W piśmie do Lammersa, szefa Kancelarii Rzeszy, Pfundtner prosił o zgodę kanclerza na tą prezentację $e^{34}$. Hitler rozkazał, by Towarzystwo Jeździeckie zostało „w sposób fair” zaspokojone finansowo, i aby tym trzem organizacjom przekazano pieniądze, pozwalające im na przeniesienie i działalność na torach w Karlshorst i Hoppengarten oraz spłacenie długu wobec Klubu Union $^{35}$.

Wspomnianą wyżej determinację Hitlera, aby dojść do porozumienia ze środowiskami jeździeckimi, wyrażało pismo H. Pfundtnera do prezydium Towarzystwa Jeździeckiego z 30 listopada 1933 roku, informujące o zakończeniu rokowań jego ministerstwa z resortem finansów na temat odszkodowania dla Towarzystwa. Minister zapraszał prezydium do gmachu Ministerstwa Spraw Wewnętrznych Rzeszy na 1 grudnia 1933 roku. W drugiej połowie grudnia 1933 roku perspektywa ostatecznego kształtu przyszłego Kompleksu Olimpijskiego uległa znacznemu przybliżeniu.

Spór między berlińską elitą sportów konnych a państwem zakończył się po myśli miłośników jeździectwa. W dniu 14 grudnia 1933 roku Klub Union i Berlińskie Towarzystwo Jeździeckie zawarło umowę ze Skarbem Rzeszy, reprezentowanym przez Ministerstwo Spraw Wewnętrznych Rzeszy. Główne postanowienia brzmiały: 1) oba towarzystwa hippiczne rezygnują z dniem 1 stycznia 1934 roku ze wszystkich swoich praw, naby-

${ }^{4}$ BABL, Rep. 1501 Nr. 5608 f. 325 i 327. Obecni mieli być także Minister Spraw Wewnętrznych, H. v. Tschamer u. Osten, W. March, J. Goebbels i H. Goering.

${ }^{35}$ H. Pfundtner, Die Gesamtleitung, in: Das Reichssportfeld, s. 16. 
tych wcześniej na mocy umów z pruskim fiskusem, dotyczących terenu toru jeździeckiego w Gruenewald, 2) Rzesza przejmuje z dniem 1 stycznia 1934 roku wszystkie umowy, jakie te towarzystwa zawarły w sprawie tego terenu $\mathrm{z}$ innymi podmiotami, 3) wszystkie zobowiązania finansowe towarzystw, które miały być uiszczone do 1 stycznia 1934 roku, przejmuje skarb Rzeszy, 4) skarb Rzeszy wypłaca Berlińskiemu Towarzystwu Jeździeckiemu za jego rezygnację ze wspomnianych praw do terenu w Gruenewaldzie odszkodowanie w wysokości 1,75 mln mk, (zawierające 750 tys. mk długu Berlińskiego Towarzystwa wobec Klubu Union), 5) pozostały milion mk należy wypłacić Berlińskiemu Towarzystwu Jeździeckiemu, Klubowi Union oraz Towarzystwu Gonitw z Przeszkodami, dla poprawy poziomu torów jeździeckich w Karlshorst i Hoppengarten oraz stworzenia funduszu nagród dla konkursów hippicznych w kwocie 300 tys. $\mathrm{mk}^{36}$.

Realizacja planów przebiegała planowo i systematycznie, w doskonałej koordynacji. W końcu 1933 roku położono fundamenty pod realizację kluczowych dla przygotowań Kompleksu Olimpijskiego obiektów i jego ideologiczno-wychowawczych zadań w przyszłości, wybiegającej poza czas samych berlińskich Igrzysk. Przemawia za tym zaproszenie wystosowane przez H. Pfundtnera do Hitlera na konferencję planowaną na 14 grudnia 1933 roku. Mieli w niej wziąć udział ludzie odpowiedzialni za przebieg przygotowań olimpijskich, m.in.: przedstawiciele Ministerstwa Spraw Wewnętrznych Rzeszy, W. March i Kierownik Urzędu Sportu Rzeszy, którzy mieli wygłosić wykłady/raporty na temat: 1) administracyjno-finansowe przygotowania projektu [H. Frick lub H. Pfundtner], 2) sportowo-fachowe przygotowanie projektu [H. v. Tschamer u. Osten], 3) architektoniczno-artystyczne przygotowanie projektu [W. March].

Prelekcje potwierdziły, że ludzie i instytucje odpowiedzialne za swoje zadania działali systematycznie i planowo, pozostając w doskonałej koordynacji i realizując „wolę Fuhrera”. Przykładowo H. v. Tschamer und

${ }^{36}$ BABL, Rep. 1501 Nr. 5609 f. 93-101: „Vertrag zwischen dem Union-Club und dem Berliner Renn-Verein e. V. einerseits und dem Reichsfiskus, vertreten durch das Reichsministerium des Innern, andererseits über Aufgabe der Rennbahn in Grünewald“; Także ogólnie: C. Diem, Weltgeschichte der Welt. Geschichte des Sports, II. Der moderne Sport, Stuttgart 1971, s. 1015. 
Osten, opisując „Forum jako centrum niemieckich ćwiczeń cielesnych”, stwierdzał, że obok celów teoretyczno-naukowych będzie ono spełniać również cele polityczne, propagandowe i wychowawcze. Podobnie Niemiecka Szkoła Wyższa Ćwiczeń Cielesnych będzie szkoliła nauczycieli m.in. dla Sturmabteilung i Hitlerjugend. Wskazywało to na to, że reżim kładł nie tylko fundamenty pod sam Kompleks Olimpijski, jego wyraz sportowy, estetyczny i przestrzenny, ale także fundamenty pod podporządkowaną ideologii nazistowskiej państwową politykę wychowawczą ${ }^{37}$. Kwestie te będą doskonalone także w przyszłości ${ }^{38}$. Uzyskanie przez państwo swobody na terenie Grunwaldu walnie przyspieszyło instytucjonalne działania. W kilka dni później powołany został „Olimpijski Wydział Budowlany”, odpowiedzialny za stały kontakt firm budowlanych z Kierownikiem Urzędu Sportu Rzeszy, także za rozdzielanie zleceń dla tych firm, wybór warsztatów i materiałów budowlanych [kamień naturalny zamiast betonu].

Równolegle do przełomowych i brzemiennych w skutki decyzji w sferze własnościowej i architektoniczno-przestrzennej na Grünewaldzie, dokonywało się doniosłe w skutkach przenoszenie kompetencji i inicjatyw elit świata sportu do nowych instytucji i ludzi, którymi nowy reżim obsadzał kluczowe stanowiska. Można założyć, że ta dynamika działań instytucji związanych strukturalnie i personalnie z Hitlerem i jego najbliższym otoczeniem osłabiała znaczenie Komitetu Organizacyjnego. W demokratycznych Niemczech Narodowy Komitet Rzeszy ds. Ćwiczeń Cielesnych był znaczącym partnerem państwa. W nazistowskiej Rzeszy, po rozwiązaniu naczelnej organizacji sportu mieszczańskiego, jego główni przywódcy, republikańsko-weimarscy funkcjonariusze pozbawieni swojej instytucji, po-

37 BABL, Rep. 1501 Rep. 5609, tutaj f. 21-43: „Das Forum als Mittelpunkt der deutschen Leibesübungen”, Berlin 11. Dezember 1933 tutaj f. 33-43. Natomiast W. March zawarł swoje dokonania w potężnym sprawozdaniu z 13 grudnia, które przesłał H. Pfundtnerowi jako podstawę swojego wykładu na konferencji. Materiał pt. „Sprawozdanie na temat architektonicznego i technicznego przygotowania obiektów Niemieckiego Stadionu Rzeszy z terenem manifestacji, Forum Sportu i Niemieckim Amfiteatrem", [tamże, f. 47-79].

${ }^{38}$ H. Bernett, Nationalsozialistische Leibeserziehung. Eine Dokumentation ihrer Theorie und Organisation, von H. Bernett, Schorndorff bei Stuttgart, 1966, m.in. Zeittafel, s. 13-16, „Das Programm der weltanschaulichen Erziehung”, s. 54-138. 
czuli nieufność nazistowskich nuworyszy i efekty ich rządów. Czuli, że byli potrzebni tylko z uwagi na ich silną pozycję w ruchu olimpijskim i samym MKOl-u). Ich rola ograniczyła się jednak tylko do wykonywania poleceń. W historiografii Ardt Krüger opisał proces manipulacji wybitnymi niemieckimi reprezentantami sportu i Olimpizmu prowadzony przez władców „nowych Niemiec”. Jego zdaniem naziści „wypychali” ich na światowe salony ruchu olimpijskiego, aby podtrzymywali wraz z niemieckimi członkami MKOl pozytywny obraz przygotowań olimpijskich prowadzonych w Berlinie. Olbrzymie zasługi Th. Lewalda na polu przekonania Hitlera do idei Igrzysk zostały szybko zapomniane ${ }^{39}$. Władcy III Rzeszy szybko zorientowali się, że bez Th. Lewalda i C. Diema i ich międzynarodowym prestiżem Berlin nie miał szans na Igrzyska, ci zaś, niezależnie od otrzymywanych od nazistów razów, wiernie trwali u boku nowych władców ${ }^{40}$. Jest to poniekąd zrozumiałe. To naziści po 1933 roku podejmowali najważniejsze i strategiczne (w tym finansowe i propagandowo-polityczne) decyzje. W tym gronie nie znalazł się ani Lewald ani C. Diem. Jak inaczej można interpretować zalecenie H. Pfundtnera wobec Th. Lewalda, wyznaczające jednemu z najwybitniejszych członków ruchu olimpijskiego i sportu w pierwszej połowie XX wieku bardzo określone - ograniczone, granice kompetencji i działania. Sekretarz stanu wyznaczył mu jako adresata idei i inicjatyw Komitetu Organizacyjnego oddanego reżimowi nominata partyjnego - von Tschamer Ostena $^{41}$ :

39 A. Krüger, Theodor Lewald. Sportführer im Dritten Reich, Berlin-München-Frankfurt n.Menem, 1975, s. 64. Gdy autor pisze o znacznym ograniczeniu wpływu Th. Lewalda i niezapraszaniu go na decydujące posiedzenia [co wynika także z analizowanego materiału - M.S.] i powołuje się na list H. Pfundtnera do H. Fricka z 13 października 1934 r., to należy stwierdzić, że proces marginalizacji przewodniczącego NKRzCC i jednego z niemieckich członków MKOl rozpoczął się późnym latem 1933 r. Cytowany niżej dokument z 13 grudnia 1933 r. jest jednym z dowodów na to.

40 Erinnerungen an Carl Diem, Michael Krüger [Hg.], Berlin 2009, s. 45-59, do oceny postawy C. Diema w okresie nazizmu, stanowiącej jedną z głównych kontrowersji w niemieckiej historiografii sportu zobacz: Die Olympischen Spiele 1948 in London im Spiegel von Carl Diems Tagebuch, hrsg. K. Lennartz, Bonn 2012.

41 BABL, Rep., 1501 Nr. 5609 f. 131-132. 
Kierownik Urzędu Sportu Rzeszy będzie pozostawał w kontakcie Z Komitetem Organizacyjnego XI Olimpiady. Proszę, aby wszystkie pomysły członków Komitetu Organizacyjnego w kwestii uksztaltowania obiektów ćwiczeń i zawodów były z nim konsultowane. On zadba o skonsultowanie tych spraw z architektem Wernerem Marchem. Proszę także pozostałych uczestników, przede wszystkim także prasę, aby we wszystkich kwestiach dotyczących programu budowy XI. Olimpiady, zwracały się wyłącznie do Kierownika Urzędu Sportu Rzeszy, który pozostaje ze mną w stałym kontakcie.

Ten sam los spotkał reprezentującego, podobnie jak Lewald i Diem, mieszczański świat W. Marcha.

Rozlegle kompetencje von Tschamer Ostena znalazły potwierdzenie w postawie ministra H. Fricka, który w piśmie z 12 stycznia 1934 roku oczekiwał, że komunikaty do prasy o przebiegu przygotowań do XI Olimpiady na polu budownictwa i sportu będą przesyłane wyłącznie przez Kierownika Urzędu Sportu Rzeszy ${ }^{42}$. Warto dodać, że ze swojej strony H. v. Tschamer und Osten starał się łagodzić negatywne wrażenie, jakie na Th. Lewaldzie i C. Diemie musiały wywołać te zalecenia. Kilka dni później wyraźnie zaznaczył publicznie, że prasa powinna podać również, że C. Diem ponosił odpowiedzialność za sportowo-fachową stronę przygotowań olimpijskich. Pod koniec 1933 roku zapadły dwie istotne decyzje. W dniu 14 grudnia Hitler ostatecznie zatwierdził plan realizacji prac na terenie Stadionu, o czym poinformowano publicznie za pomocą mediów ${ }^{43}$. Cztery dni później odbyło się spotkanie mające na celu powołanie Komisji Budowlanej, która miała być odpowiedzialna za fachową realizację projektu

42 BABL, Rep. 1501 Nr. 5609: „Pressenotitz. Pressenachrichten über die bauliche und sportliche Vorbereitung der XI. Olympiade”, Berlin, den 12. Januar 1934, f. 151.

${ }^{43}$ H. Bernett, H.J. Teichler, Olympia, s. 144; K. Stöckel, Berlin, s. 17. Także obszernie do powstałej w obrębie Kompleksu Olimpijskiego infrastruktury, w tym do składowych Forum Sportu. Stadion Olimpijski liczył 27 m wysokości; 35 z 70 rzędów z miejscami do siedzenia zostało wpuszczonych w ziemię, tak, że górna część wystawała $12 \mathrm{~m}$ nad powierzchnię ziemi. 
budowy, w tym głownie koordynację zadań wszystkich instytucji, zaangażowanych w Kompleks Olimpijski ${ }^{44}$.

W kwietniu 1934 roku rozpoczęły się prace budowlane pod nadzorem W. Marcha. Na obszarze ok. 500 hektarów pracowało 2,6 tys. robotników i 500 firm. Oficjalne wydawnictwo „Urzędowe sprawozdanie z XI Igrzysk Olimpijskich 1936" ocenia koszt budowy Kompleksu na sumę $36 \mathrm{mln}$ mk. R. Rürup w swoim opracowaniu podał inne sumy. Jego zdaniem koszty budowy, początkowo szacowane na $27 \mathrm{mln}$ mk, wzrosły w 1936 roku do pond $40 \mathrm{mln} \mathrm{mk}$. Dokładne koszty nigdy nie zostały opublikowane ${ }^{45}$.

Nowy koncept, opracowany przez W. Marcha, był w swoich głównych liniach gotowy już 21 października 1933 roku. Do publicznej wiadomości podał go „Volkischer Beobachter” w dniu 14 grudnia 1933 roku. Nowy obiekt stawał $\mathrm{w}$ jednym rzędzie z różnymi nowymi budowlami monumentalnymi, jakie powstały w Monachium, Norymberdze i innych częściach Niemiec. Jako dzieło III Rzeszy nadano mu funkcję dokumentowania odzyskanej politycznej siły kształtowania losu Niemiec i odzyskanych sił wspólnoty narodowej, hamowanych przez Republikę Weimarską. W tym sensie słowa Hitlera „Będziemy budować!” były czymś więcej niż tylko subiektywnie motywowanym wyrazem woli. Symbolizowało to bardziej wolę odnowienia całego systemu nazistowskiego ${ }^{46}$. W ogromnej masie informacyjno-propagandowych materiałów olimpijskich, Kompleks Olimpijski, a szczególnie Stadion Olimpijski, zajmowały eksponowane miejsce ${ }^{47}$.

${ }^{44}$ BANL, Rep. 1501 Nr. 5609 f. 109-119. „Besprechung vom 18. 12. 1933 über die Errichtung eines Bauauschusses für die Olympiade". Obecnych było 5 osób: H. Pfundtner, H. v. Tschamer und Osten, W. March i dwóch wyższych urzędników z Ministerstwa H. Fricka. Komisję tę powołał minister spraw wewnętrznych Rzeszy jeszcze w grudniu 1933 r. Kwestie budowlane i architektoniczne w niej przekazano W. Marchowi, wspieranemu przez Schultze-Naumburga i Steinmetza. [Das Reichsportfeld, s. 16-17].

45 R. Rürup, 1936. Die Olympischen Spiele/1936. The Olympic Games, s. 65. W „Urzędowym Sprawozdaniu Komitetu Organizacyjnego” Igrzysk podano sumę $36 \mathrm{mln}$ mk: Organisationskommitee für die XI. Olympischen Spiele in Berlin 1936, Bd. 1. Amtlicher Bericht, Berlin 1937, s. 67, 137.

46 Th. Alkmeyer, Körper, s. 316.

${ }^{47}$ Np. W. Schluter, Von Athen nach Berlin. Führer zu den Olympischen Spielen Berlin 1936. Vorwort vom Staatsrat Görlitzer, Berlin 1936, s. 22-25. 
Propaganda już od jesieni 1933 roku intensywnie podkreślała decydującą rolę kanclerza w nadaniu projektowi obiektów olimpijskich imponujących rozmiarów i bogactwa jego składowych. Przy tej okazji przekazano niemieckim masom nowy slogan propagandowy: „Stadion 100 tysięcy”. Publicznie podkreślano, że krążące od lat plany przebudowy Stadionu Niemieckiego na Grunwaldzie, które przez długi czas nie mogły być ujednolicone i skonsolidowane zostały za sprawą Hitlera szybko skoordynowane i wprowadzone do życia. Pisano, że nieoczekiwana wizyta Adolfa Hitlera podczas kursu młodych olimpijczyków prowadzonym w Forum Sportu przyniosła przełomowe rozstrzygniecia. Führer odrzucił połowiczne rozwiązania na korzyść pełnowartościowych, aby pokazać światu jak ważna dla Niemców jest aktywność fizyczna. Jego koncepcje były zgodne z planami Ministerstwa Spraw Wewnętrznych i Kierownika Urzędu Sportu Rzeszy, którzy także chcieli stworzyć na Grunwaldzie coś, czego niemiecki sport potrzebował od lat ${ }^{48}$. Ten artykuł i jego język wyrażał postawę elity nazistowskiej, dla której Kompleks Olimpijski, jak i rola opiekuna idei olimpijskiej w Niemczech były instrumentem budowy kultu Hitlera i umacniania reżymu narodowosocjalistycznego w kraju i za granicą.

Wracając do modyfikacji pierwotnych planów stadionu, w toku dyskusji porzucono plany zadaszenia Stadionu, aby zachować antyczne wzory. Na wniosek Hitlera, Albert Speer zamienił, zaprojektowane przez W. Marcha na wzór wiedeńskiego Stadionu, szklane ściany na kamień murarski z wapna muszlowego ${ }^{49}$. Pomimo wszelkich zmian ostateczna koncepcja Stadionu zachowała wiele z pierwotnych projektów, np. betonowy szkielet,

${ }_{48}$ Olympia-Stadion der 100 000, Berliner-Zeitung-Mittag, Nr. 248, 17. Oktober 1933, inserowany w: BABL, Rep. 1501 Nr 5609 f. 357-371. „Stadion Olimpijski winien być symbolem niemieckiej kultury i niemieckiej siły”. Jest znamienne, że w artykule nie pada nazwisko przewodniczącego Komitetu Organizacyjnego, ani jego sekretarza generalnego [tzn. Th. Lewalda i C. Diema-M.S.].

${ }^{49}$ Th. Alkmayer, Gewalt-und Opfer, in: Körper - und Einbildungskraft, s. 51. „Aby podnieść oddziaływanie sceniczne, Speer zredukował oddane formie kolażu elementy stylu do ich form zwyczajnych i zmienit ich dymensje i proporcje. W ten sposób powstała typowa dla późniejszych budowli nazistowskich siła promieniowania monumentalizmu. Została ona jeszcze w wypadku Stadionu Olimpijskiego zwielokrotniona przez szczególny optyczny i emocjonalny efekt. Stadion górował nad miastem, był z daleka widoczną, samotną budowlą". 
prążkowane powierzchnie kamienne, wąskie podpory betonowe z wprowadzonym między nie przeszkleniem, czy dwupiętrowe arkady Stadionu Pływackiego. Stare koncepcje zostały ukryte przez surowy kamień. Zmiana architektonicznego wyrazu wiązała się przede wszystkim z nadaniem temu obiektowi nowego znaczenia - politycznego. Naturalny materiał kamienny miał sugerować nazistowskie tęsknoty do rodzimości, skromności, trwałości, zdolności stawiania czoła przeciwieństwom, wielkości i władzy. Naturalny kamień miał również symbolizować „niewzruszoną siłę niemiecką i zdolności obronne nazistowskiego światopoglądu ${ }^{50 ”} . \mathrm{Z}$ mieszaniny technicznej racjonalności, zachwytu techniką, instrumentalnej logiki i antycywilizacyjnych fobii wywodzi się niezwykłość berlińskich obiektów olimpijskich. Posiadają one rzadką aurę sąsiedztwa mitycznej sakralności, monumentalnej fantazji i funkcjonalności ${ }^{51}$. Zamknięciem ważnego etapu ofensywy olimpijskiej propagandy reżymu była urzędowa publikacja pt. „Olimpia - nasze zadanie narodowe”. Na pierwszych stronach ukazano (przełomową w skutkach) wizytę Hitlera na Grünewaldzie 5 października 1933 roku z obliczem natchnionego wizjonera instruującego towarzyszących mu H. Fricka i kierownika Urzędu Sportu Rzeszy. W tej publikacji nie starano się nawet stwarzać pozorów udziału w tych zdarzeniach mieszczańskich członków Komitetu Organizacyjnego Igrzysk XI Olimpiady ${ }^{52}$.

Historia nazistowskiego Stadionu Olimpijskiego w Berlinie wiąże się nierozerwalnie z dwoma, symbolicznymi wydarzeniami - triumfem niemieckiego sportu na Igrzyskach Olimpijskich w 1936 roku i hańbie związanej z propagandą zbrodniczego reżimu. Otwiera ją złoty medal przyznany

50 Th. Schmidt, Skizze, s. 251.

51 Th. Alkmeyer, Körper, s. 341, 346; H. Bernett, Zeichen der Macht. Die Symbole und Zeremonielle der Spiele von Berlin 1936, w: Olympia-Berlin, s. 6-7; Th. Alkmeyer, Körper, s. 341, 346; Ich rufe die Jugend der Welt. Olympische Spiele Berlin 1.-16. August 1936. IV. Olympische Winterspiele Garmisch-Partenkirchen Februar 1936, Berlin 1934, s. 15,20 i 21.

${ }^{5}$ Olympia-unsere nationale Aufgabe. Im Auftrage des Reichssportführers und des Propagandaauschusses für die Olympischen Spiele 1936, Berlin, bearbeitet von Dr. Gerhard Krause und Erich Mindt. Mit einem Geleitwort des Reichssportführers von Tschamer und Osten, Berlin 1936, s. 85-115: opis planowanych obiektów olimpijskich i Wioski Olimpijskiej. 
jego oficjalnemu projektantowi - Wernerowi Marchowi w konkursie literatury i sztuki ${ }^{53}$, a także, utrzymana w duchu obrazu pokojowych Niemiec, „Noworoczna Odezwa” Th. Lewalda (przypomnijmy - prezydenta Komitetu Organizacyjnego XI Olimpiady) i H. v. Tschamera u. Osten (prezydenta Niemieckiego Komitetu Olimpijskiego) do świata" ${ }^{54}$.

Oby nowy rok, pierwszy XI Olimpiady, przyniósł pozytywny przebieg olimpijskich rywalizacji i uroczystości i tym samym spełnił życzenia i tęsknoty, które żywimy w stosunku do niemieckiej młodzieży, jak i wobec wszystkich innych biorących udział w tej pięknej imprezie.

Historię Stadionu Olimpijskiego zamyka propaganda zbrodniczego reżimu i bezsensowna ofiara śmierci 2 tys. młodych chłopców zrzeszonych w Hitlerjugend z dywizji „Grossdeutschland”, który polegli na jego terenie w walkach z Armią Czerwoną w 1945 roku $^{55}$.

Sformułowanie Hitlera, który „sztukę budownictwa” partyjnych (państwowych) obiektów nazywał „słowami z kamienia” można przenieść również na obiekty sportowe, czego przykładem jest Kompleks Olimpijski w Berlinie. W ciągu dwóch lat zbudowano nowy obiekt dowodzący „odrodzonej witalności Niemiec pod wodzą Hitlera" ${ }^{56}$. Nazistowski dyktator nie mógł wiedzieć, że gdy 5 października 1933 roku wizytował tereny przyszłego Kompleksu Olimpijskiego, niespełna trzy lata później osiągnie m.in. dzięki Igrzyskom polityczny sukces. Tak wielki, że jeszcze w 1939 roku MKOl postanowił, by VII Zimowe Igrzyska Olimpijskie rozegrać ponownie w Niemczech ${ }^{57}$. Służby dyplomatyczne nazistowskich Niemiec opisy-

53 W. Lipoński, Sport, obszernie na s. 536-542. Także G. Młodzikowski, Instytucje ruchu olimpijskiego, w: Kultura fizyczna, s. 169.

${ }^{54}$ G. Rühle, Regierungsrat, Mitglied des Reichstages, Das Dritte Reich. Dokumentarische Darstellung des Aufbaues der Nation. Das vierte Jahr 1936, Berlin 1936, s. 173 [Olympische Spiele 1936].

${ }^{55}$ H. Geyer, Olympische Spiele 1896-1996. Ein deutsches Politicum, Münster 1996, s. 19.

${ }^{56}$ Th. Alkmeyer, Gewalt und Opfer, s. 47.

57 S. Günther, Die Berliner Olympiade von 1936 und ihre Außenwirkung: Weltereigniss oder Propagandaveranstaltung?, Bamberg 2005, s. 20; zob. S. Endlich, Olympische Spiele, 
wały wszystkie przychylne Igrzyskom reakcje płynące ze świata ${ }^{58}$. Hitler mógł śmiało planować wspaniałą infrastrukturę wiedząc, że ma u swojego boku jeden $\mathrm{z}$ największych na świecie ruchów sportu i kultury fizycznej. Ruch, który w Republice Weimarskiej przeżywał okres liczebnego prosperity. Naziści przejęli po Republice wybudowane lub budowane w całych Niemczech liczne obiekty sportowe, a także prężnie rozwijającą się naukę o sporcie ${ }^{59}$. Pozytywne rewolucje wzmacniały dodatkowo przemiany kulturowe lat dwudziestych XX wieku, w których sport i nastroje młodości trafiały na coraz podatniejszy grunt. Założenie, że do przyszłej planowanej walki o „przestrzeń życiową” ma stanąć jeden z najbardziej usportowionych narodów świata zmusiło nazistów do pełnego podporządkowania sportu ideologicznym i politycznym celom. W tej mierze panuje w historiografii od przynajmniej dwóch dekad zgoda. Nikt już nie stawia problemu instrumentalizacji ruchu turnerskiego i sportowego przez nazistów, która automatycznie stawiała ich w roli „ofiar”. Obecnie badacze problemu nazizmu stawiają pytanie o rolę działaczy sportowych, jako ciał działających i sprawczych w procesie zdobycia władzy przez narodowych socjalistów, współtwórców Volksgemeinschaft i ich kumulatywnej radykalizacji w 1933 roku $^{60}$.

w: Enzyklopädie des Nationalsozialismus, hrsg. von W. Benz, H. Graml, H. Weiss, München 2001, s. 625.

58 BABL, R 55 Nr. 1054, Reichsministerium für Volksaufklärung, Die Olympiade in Berlin 1936 im Spiegel der ausländischen Presse; Berichte nach Alphabet der Länder [vermutlich von der deutschen Auslandsvertretung], 1936, m.in. W. Brytanii f. 20-45.

59 Was wir wollen! s. 1, Das Steinstossen, s, 2-3, Deutsche Athletik SportZeitung, Stuttgart, 5. Juni 1919 1. Jg,; T.Z., Die Eröffnung der deutschen Hochschule für Leibesübungen, DTZ, Nr. 22. Leipzig, 27. Mai 1920 s. 180; Die deutschen Sport-und Turnverbände, Jahrbuch der Leibesübungen für Volks-und Jugendspiele, Jg. 31, 1924, s. 236-238, 270. W 1924 r. same mieszczańskie organizacje sportu i kultury fizycznej liczyły ok. 5,7 tys. członków, w tym Niemieckie Turnerstwo 1,75 tys. osób. W 1931 r. organizacje sportu oraz kultury fizycznej i turystyki liczyły już 7,605 tys. członków. Ch. Eisenberg, Massensport in der Weimarer Republik, Ein statistischer Überblick, Archiv für Sozialgeschichte, Bd, 33, 1993, s. 149-150, 168.

${ }^{60}$ L. Peiffer, Sport im Nationalsozialismus. Zum aktuellen Stand der sporthistorischen Forschung. Eine kommentierte Biographie, Göttingen 2009, s. 19. Do nadgorliwości m.in. kierownictwa niemieckiego futbolu zob. Fussball in Vergangenheit und Gegenwart, Bd. 1. Geschichte des Fußballsport in Deutschland bis 1945, Autorenkollektiv, M. Zöller: Leiter, Berlin 1976, s. 147-149. 